\title{
Arthur Earland: the foraminiferal slide collection and correspondence at the University of St Andrews, Scotland
}

\author{
M. ROBINSON \& W. E. N. AUSTIN \\ School of Geography and Geosciences, University of St Andrews, Irvine Building, St Andrews, Fife KY16 9AL, Scotland, UK.
}

\begin{abstract}
Arthur Earland and D'Arcy Wentworth Thompson corresponded for a period of over fifty years between 1894 and 1946. During this interval Earland supplied Thompson with Foraminifera for his growing museum collection at the University of Dundee. Following Thompson's move to the University of St Andrews in 1917, a new collection was started. The content, general state, and labelling of the 405 slides in this collection are described. Earland's correspondence with Thompson provides a rare insight into the early twentieth century approach to scientific research by the interested amateur and sheds new light on the nature of Earland's long working relationship with Edward Heron-Allen. J. Micropalaeontol. 20(2): 97-122, December 2001.
\end{abstract}

\section{INTRODUCTION}

Arthur Earland's (1866-1958, Fig. 1) name is noted among British foraminiferal workers and is closely allied with his long-time research collaborator, Edward Heron-Allen (see Hodgkinson, 1989). His contribution to foraminiferal research stands out amongst a long line of nineteenth and early twentieth century British amateurs, including H. B. Brady (a chemist), J. M. Flint (a surgeon) and J. Wright (a grocer); all of

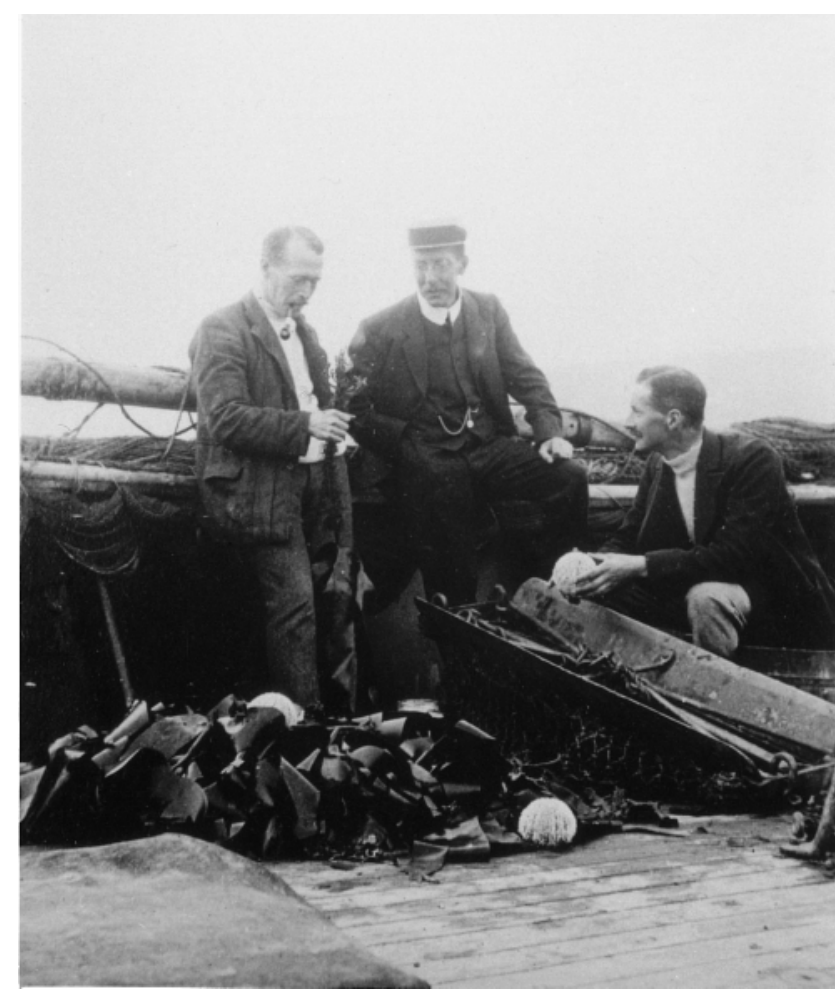

Fig. 1. Arthur Earland (centre), pictured with G. P. Farran and R. Sothern, both seamen with the Irish Fisheries Board, aboard the Irish Fisheries Cruiser Helga (date unknown). This photograph is reproduced with the permission of the Keeper of Manuscripts, St Andrews University Library (ms. 45789). whom appear to have been captivated by the extraordinary architecture and beauty of these single-celled protozoans. This was the age of the so-called 'English School' (Haynes, 1981), and the belief that the foraminifera were a simple, plastic group, with species ranging through much of the stratigraphic record. Such views, together with the mechanistic ideas of D'Arcy Thompson (On Growth and Form, 1917) who, like Williamson (1858), believed that the diverse shape variations in, for example, the genus Lagena were not specific, greatly influenced the study of smaller foraminifera at this time.

This passion for foraminifera appears to have come from Earland's early mentor, Edward Halkyard, whom he first met at the Royal Microscopical Society between 1885 and 1888, and with whom he was subsequently acquainted as a member of the Quekett Microscopical Club (Hedley, 1958; Morley-Jones, 1958). By 1891 he had published his first paper on foraminifera (Earland \& Cooke, 1891). However, it is the publication in 1908 with Heron-Allen (Heron-Allen \& Earland, 1908), of the first of 38 joint papers that included the description of over 200 new species and varieties of foraminifera (Hodgkinson, 1989), which marks the beginning of one of the most significant partnerships in foraminiferal research from this era.

\section{THE EARLAND-THOMPSON SLIDE COLLECTION}

The slide collection, which consists of 405 assorted slides, is housed in the Bute Building, University of St Andrews, in a wooden cabinet labelled 'Foraminifera presented by Arthur Earland'. A summary of the material, comprising more than 1500 Foraminifera specimens, and labelling of the slides is given in the Appendix (Table A1). Much of the material is rather dusty, many of the slides remain uncovered and presumably are, as Earland supplied them, 'mounted on the "Brady" principle' (letter dated 11.06.1894). The latter, mostly consisting of cardboard slides $(76 \times 25 \mathrm{~mm})$ with a single round cell and black background (Fig. 2), are generally uncovered and differ from the typical Heron-Allen and Earland Type Slides housed at the Natural History Museum, London (Hodgkinson, 1989). A few of this type are present and comprise an additional paper sheath and glass cover slide. Earlier slides are generally of wooden 

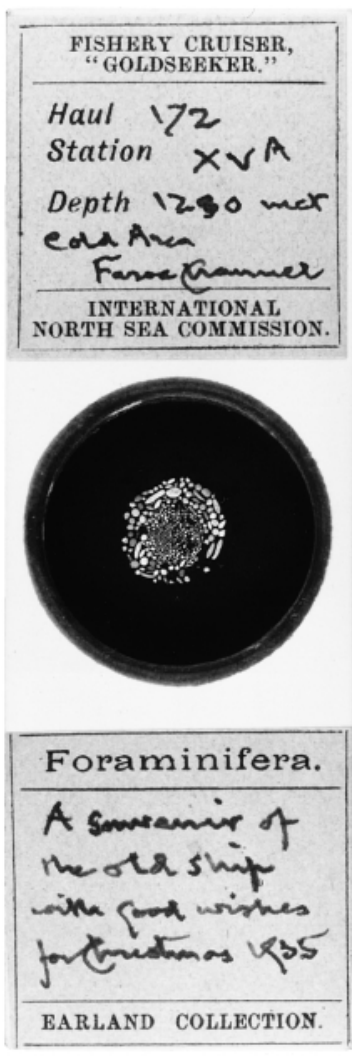
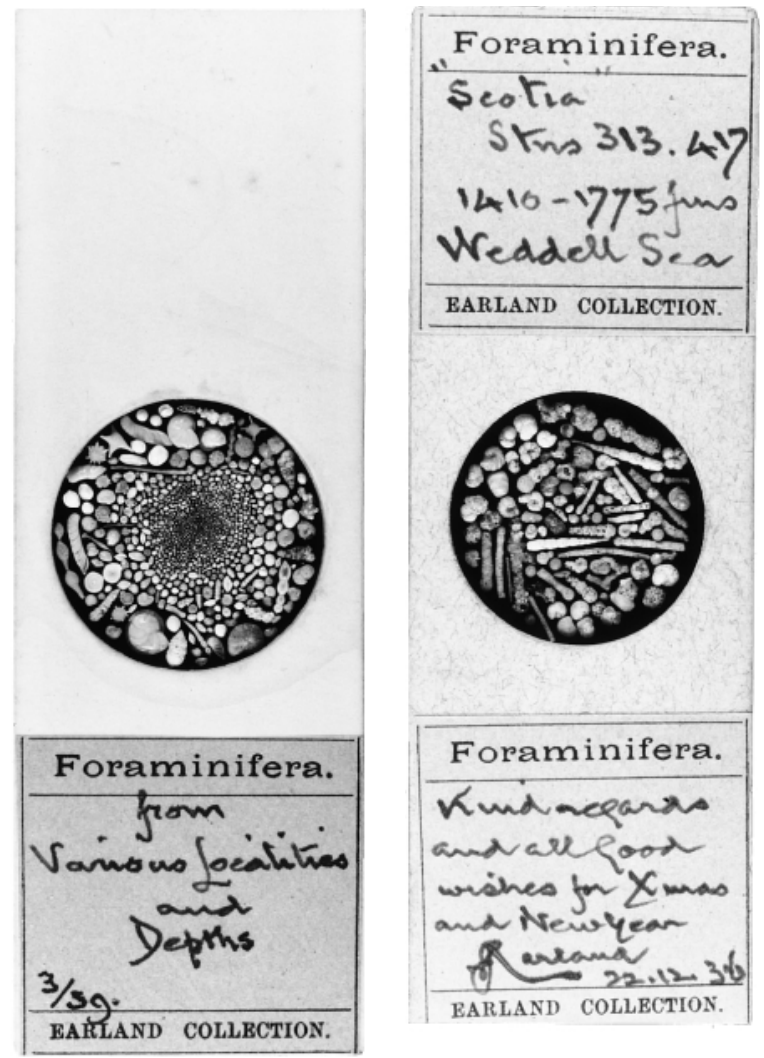

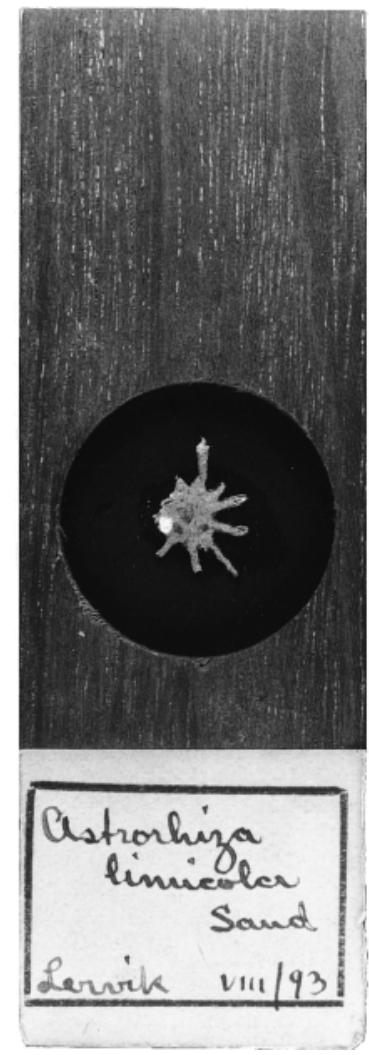

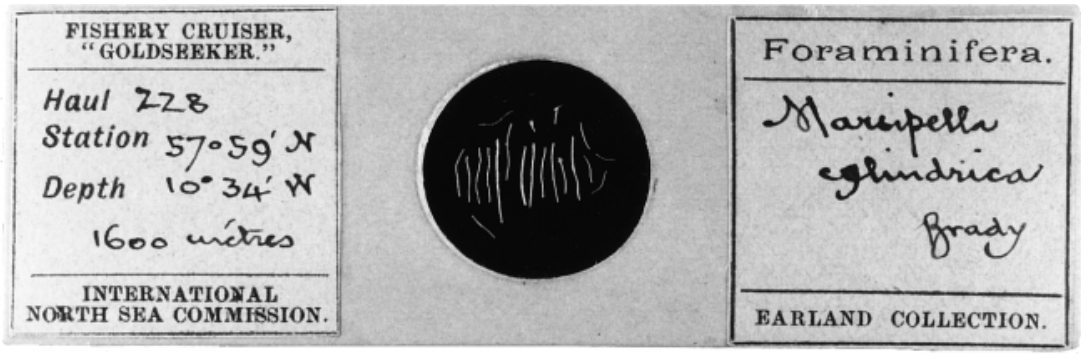

Fig. 2. Examples from the Earland-D'Arcy Thompson Foraminiferal Slide Collection. All hand-written by Earland. The reference on the slide prepared as a Christmas greeting in 1935 to 'the old ship' is the F.C. Goldseeker, which was replaced in 1922 by the Explorer (Rice, 1986). Actual slide dimensions $76 \times 25 \mathrm{~mm}$.

construction, e.g. Astrorhiza limicola collected off Lerwick in August, 1893 (Fig. 2).

In addition to the 'Earland Collection' labels, various other forms of printed slide labelling are present in this collection, notably 'selected by Charles Elcock', 'Joseph Wright's Collection', and 'G. W. Chaster', but it is not clear whether all the slides originated from Earland. Hodgkinson (1989) notes that some of the earlier slides in the Heron-Allen and Earland Type Slide collection are marked 'Charles Elcock, Belfast' and were probably gifts. In the case of Psammosphaera fusca, which is present on a slide labelled 'selected by Charles Elcock' (Table A1), it seems highly unlikely that a species described by Heron-Allen and Earland from the North Sea cruises of the Fisheries Cruiser (F.C.) Goldseeker (Fig. 3) would have been supplied by Elcock. However, Chaster and Wright may have independently supplied Thompson with material for his collection.

Many of the specimens in this collection could potentially be regarded as topotype material (i.e. specimens that come from the same locality as the holotype) or, more significantly in the case of Heron-Allen and Earland's work, syntype (where no holotype was defined from the original type material). Hodgkinson (1989) details the sense in which 'type' was often used in reference collections of that time and also notes, from a letter of about the same period, that it was Earland who 'provided identifications, described new species, supervised artists and made up the plates'. Given that Earland himself picked 'representative' material for Thompson, the significance and value of this collection deserves wider recognition and further examination. 


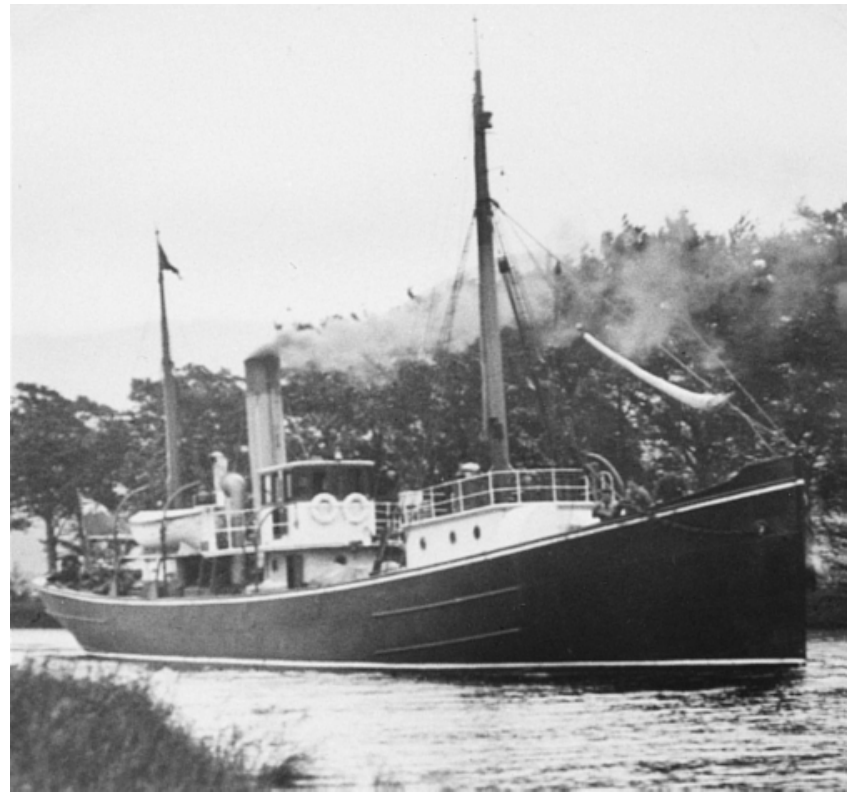

Fig. 3. The Fisheries Cruiser Goldseeker in the Caledonian Canal, Scotland (date unknown). Built in 1900, weighing 206 tons gross, $116 \mathrm{ft}$ long and $21 \mathrm{ft}$ beam, the F.C. Goldseeker undertook biological and hydrographical observations in the northern North Sea and in the Faroe-Shetland Channel as part of the British contribution to the International Council for the Exploration of the Sea (Rice, 1986). This photograph is reproduced with the permission of the Keeper of Manuscripts, St Andrews University Library (ms. 45789).

\section{THE EARLAND-THOMPSON CORRESPONDENCE} 10 Glenwood Rd., Catford, S.E.

June 11, 1894.

My dear Sir,

I have to acknowledge the receipt of your letter of the 6th. inst. I should be very pleased to send you some slides of Foraminifera, but have none or very few on hand as I make nearly all my exchanges in unmounted named specimens. I enclose you a list of species all named and localized of which I can supply specimens, and if your Museum authorities like to defray the cost of the slips for mounting, I shall be very pleased to prepare you 100 or 200 representative forms from the list.

They would be mounted on the 'Brady' principle in sunk cardboard cell slides, which are kept turned upside down in the cabinet. My own collection is mounted entirely on this plan which has the advantage of being simple of access and more lasting than a glass mount if kept in a dry place.

If you don't feel inclined to accept the offer, please return my list, and I send you a type slide of the principal genera in exchange for your Astrorhizidae and Rhabdammina.

Yours very truly,

\section{A. Earland \\ D’Arcy W. Thompson Esq. Quekett Microscopical Club}

The foregoing is the first of 125 letters written by Arthur Earland to the polymath Sir D'Arcy Wentworth Thompson, during the period 1894 to 1946 , which are housed in the Library of the University of St Andrews (Appendix, Table A2). This and other quotations are published here by permission of the Keeper of Manuscripts, St Andrews University Library. The collection also contains a smaller number of letters from Thompson, but these are not considered here. The distribution of correspondence throughout the period is uneven, about half the letters being written before 1910, and very few dating from the 1920 s and 1930s.

Earland's letters span a large part of his life, the correspondence commencing when he was 28 in 1894 and ending in 1946, 12 years before his death at 91 years of age (Thompson died in 1948). During this period Earland lived at Catford and Watford, whilst working in the Savings Bank Department of the General Post Office (becoming Principal in charge of War Loan Redemptions in 1920); in Hastings and Edinburgh after his retirement; and finally in Broughty Ferry (near Dundee) with his daughter Iris Ramsay and her family. Thompson was Professor of Biology at the University of Dundee where, amongst other pursuits, he established a museum; hence Earland's initial involvement with him as a supplier of mounted Foraminifera specimens. In 1917 Thompson moved to the University of St Andrews and Earland, supposing the museum collection assembled over so many years to have been left behind in Dundee, offered to supply some more mounts for teaching purposes: 'I have still some of your slides left so they would cost you nothing and me nothing more than the trouble of picking out specimens as I come across them.' (2.7.1921). It seems probable that this second collection comprises the 405 slides of Foraminifera referred to above, which were stored together with about 90 diatom slides in one cabinet. (The diatom slides are currently on loan to the Royal Botanic Garden, Edinburgh.)

The correspondence is primarily concerned with Earland's work undertaken for Thompson: the examination of Foraminifera and the provision of 'types', mainly through the cleaning of material supplied by Thompson from Arctic waters (Greenland), the Challenger expedition and, principally, the North and Norwegian seas. Earland's own early collection contained few deep-water gatherings, mainly comprising coral sands and mud of littoral deposits, and he was keen to extend it: 'I am always glad of material from any locality, recent or fossil, which contains Forama. as I make a special study of the distribution of species, and am consequently glad of stuff containing even the commonest forms' (27.10.1894). This concern with distribution continues and letters from 1908, for instance, contain interesting ideas formulated by Earland on the basis of collections from stations in the North Sea. These were summed up thus (23.10.08):

The North Sea foraminifera were originally cold or arctic in type; they now present a mixture of cold and warm types; the warm types have immigrated into the area around the north of Scotland being most numerous in the area round the Pentland Firth and in the North of Moray Firth; they have worked their way southwards displacing the older cold fauna which still lingers on in some few localities where it is probably protected by local conditions from the influx of warm Atlantic water. 

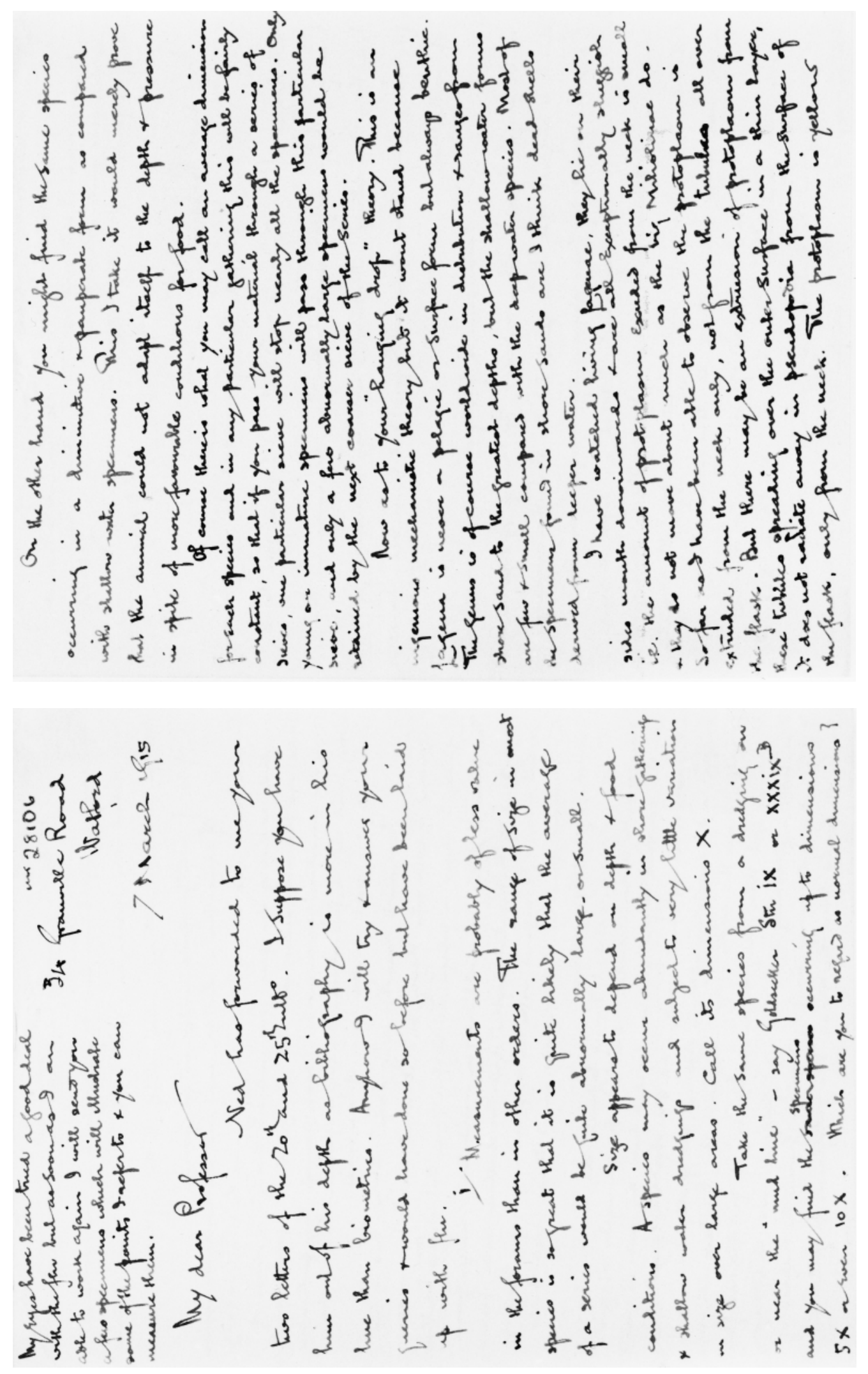


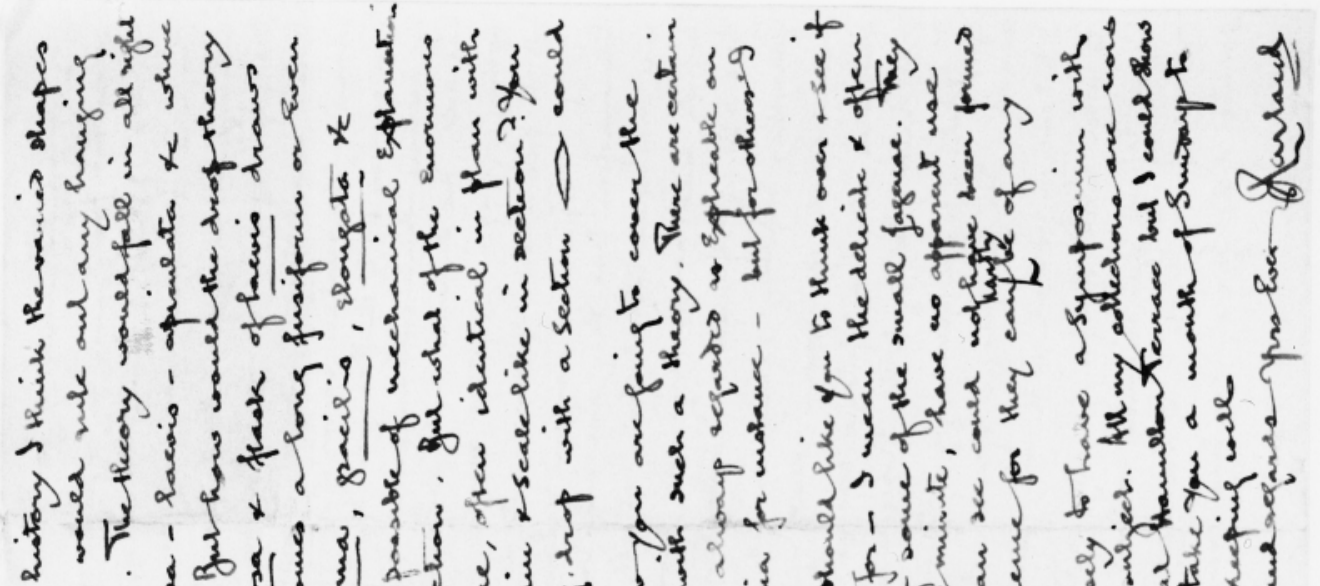
$+4 \ln ^{2}$

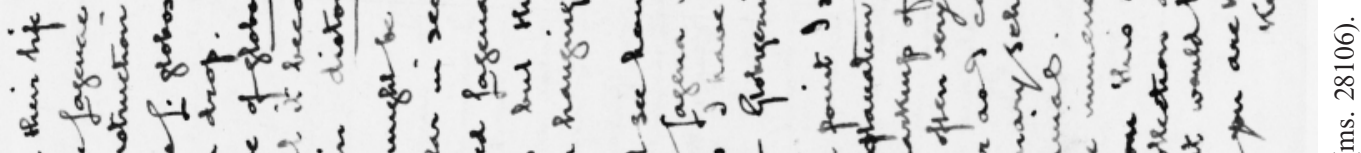

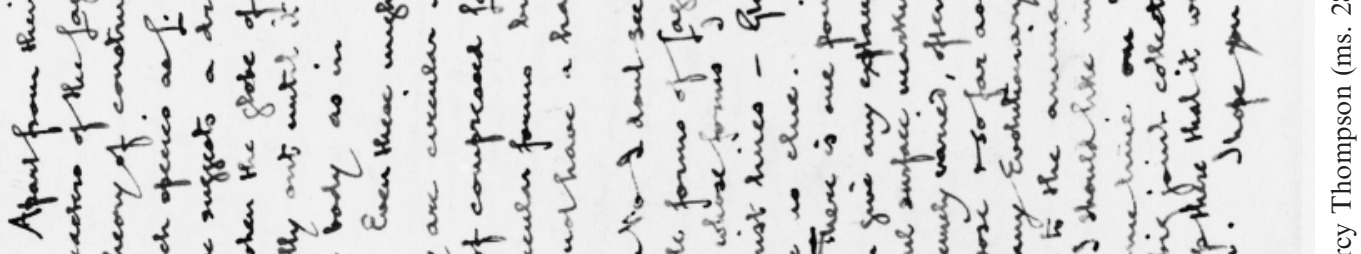

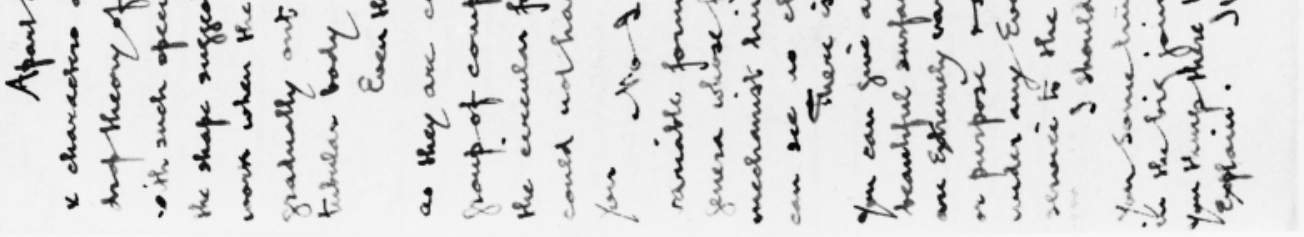

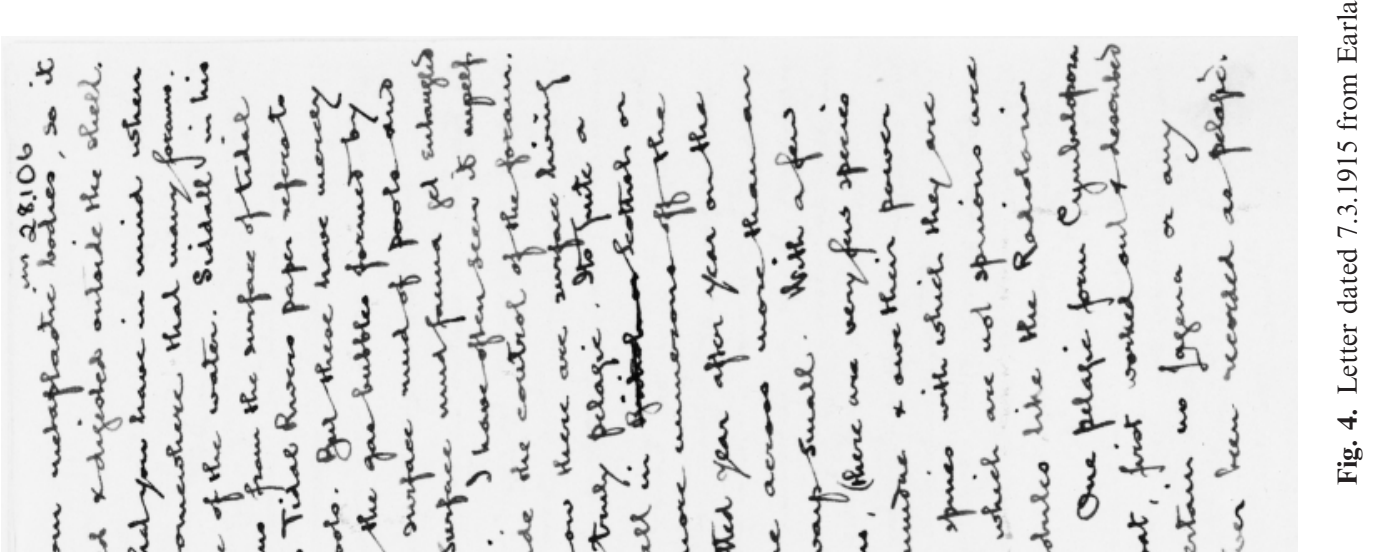

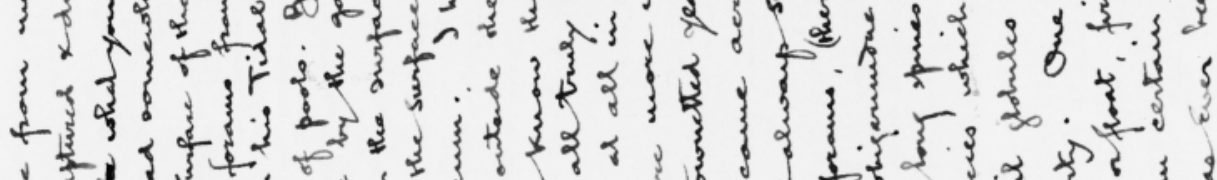
thy

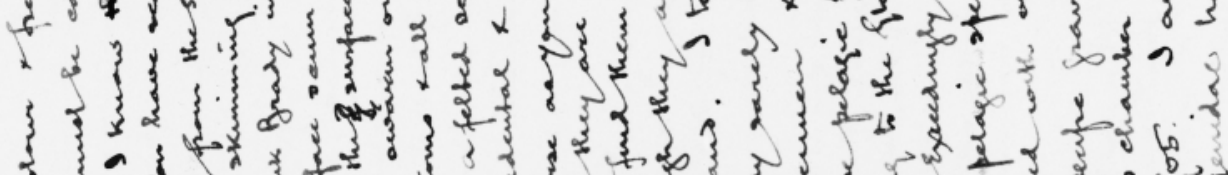

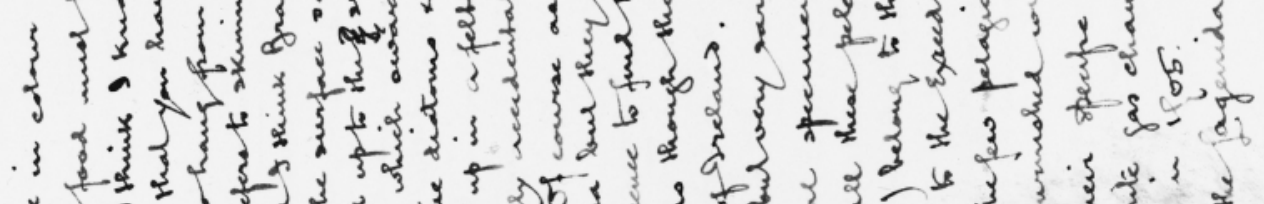

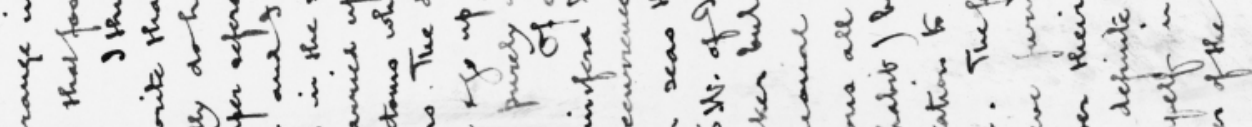

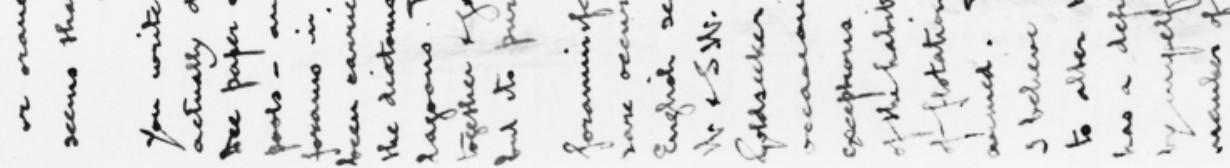


By 'local conditions' Earland meant submarine topographic ridges.

Earland was also intrigued by the occurrence of chalk fragments in some Moray Firth (Kinnaird Deep) dredgings where he understood that only older rocks should occur ('It is rather too much to believe that they have traveled with the drift from say Yorkshire or across the North Sea') (1.1.1908). Discussions with an interested geologist, $\mathrm{Mr}$ W. Hill, resulted in a paper being written on the topic (Hill, 1915). Another topic of concern, which Earland referred to Thompson for help, was the

minute chitinous spherical body which often occurs in myriads in N. Sea dredgings ... I think they are probably Infusoria (Peridiniaceae) but have spent some time at B. Museum with Dr. Colman's assistance without result. They agree in dimensions with the well known 'spheres' of the Chalk which are certainly not forams. (9.1.1909)

Thompson helped Earland by supplying some of the necessary equipment such as metal sieves and silk gauze used in the separation and extraction of specimens by 'rocking and spinning'. In the early years of this century they debated the merits and demerits of Earland's manual technique and Thompson's new centrifugal method of separation (Earland remaining unimpressed by the latter). Copies of papers on Foraminifera were also supplied by Thompson and, later, a cabinet of drawers for cleaned material. Publication of some of Earland's reports was also assisted by Thompson (e.g. letter of 3.7.1911).

Amongst the most detailed letters are the accounts of Earland's North Sea voyages on the hydrographic research vessel Goldseeker, arranged by Thompson as head of the International Committee for Investigation of the North Sea (Scotland). Earland greatly enjoyed these trips taken during annual leave from 1907 onwards until 1910 or 1912 as a break from 'the monotony of life in a Government office', and looked back on them as 'amongst the most enjoyable days of my life' (25.10.1944). He recognized the value of seeing samples being collected and better appreciated the practical problems. Refinement of the techniques and equipment used resulted and new dredging stations were added to the agenda. Earland's powers of observation emerge in his description of one specimen recovered from North Sea station 11A,

a pebble covered with a colony of Saccammina sphaerica in the sessile stage \& with a young brood of individuals surrounding the colony. This is a most valuable find from a biological point of view $\&$ is doubly interesting for the reason that the large individuals are covered with an armour of sponge spicules built in for defensive purposes with the points radiating in all directions. (13.8.1909)

Findings in the North Sea on the geographical ranges of some types led him to query some published ideas on habitats (water depth and temperature, in particular). He also questioned Rhumbler's hypothesis that Saccammina sphaerica was the adult form of Psammosphaera fusca, since he knew that the two did not occur together in Goldseeker dredgings (20.7.1910).

The letters from around this time show that Earland was much concerned with the form of the foraminiferal test and, especially how and why they developed particular structures. He believed that certain forms could only imply the existence of 'selective or discriminative powers', a kind of 'intelligence', as opposed to the 'mechanistic theory of construction involving simply gravity and surface tension' (3.7.1911 and 19.7.1911). Later (7.3.1915, Fig. 4), he asks Thompson to consider, and offer an explanation for,

the delicate $\&$ often beautiful surface markings of some of the small Lagenae. They are extremely varied, often very minute, have no apparent use or purpose \& so far as I can see could not have been formed under any evolutionary scheme for they can hardly be of any service to the animals.

Doubtless he was not the first or last to ponder that particular question.

Much of Earland's work on material gathered on the Goldseeker voyages appears to have been published between 1912 and 1917 under the joint authorship of Edward Heron-Allen and Earland (Hodgkinson, 1989). Heron-Allen collaborated amicably with Earland for nearly 30 years, the former financing the essential illustrations of new forms for publication, and working together with Earland on their large joint collection of foraminifera housed (certainly in 1915) at Heron-Allen's London home in Hamilton Terrace. After removal of the collection to the British Museum (in the 1930s?) Heron-Allen and Earland ceased to collaborate, a source of regret to Earland at least, forming a final and rather bitter schism for which he later accepted no blame (5.9.1933). Unfortunately, many of the later letters after Heron-Allen's death in 1943 are largely concerned with this episode. However, even in the mid-1940s, Earland was still sending slides to Thompson and discussing types and methodology.

Throughout the correspondence there are references to other aspects of Earland's life and career. For several years from 1903 on, he was Hon. Secretary of the Quekett Microscopical Club, responsible for arranging meetings for about 100 members every two weeks throughout the season. Later that decade he mounted an exhibition of Arenaceous Foraminifera at the Club, only to suffer the loss of one of his best specimens of Technitella thompsonii (named by Earland after D'Arcy Thompson), a species which he believed demonstrated the 'selective power' of certain Foraminifera particularly well (20.3.1909). (An account of the lecture and exhibition is contained in the Proceedings of the meeting on 1.1.1909, J. Quekett Microscopical Club, 10, 479-483.)

There are references in the letters to Mrs Earland and at least three children. One son, Vivian, was at the age of nearly 16 ('At present he seems to have no tastes beyond football etc.') taken on the Goldseeker in an effort to broaden his horizons, since 'Watford is a very little world and it is almost all he can imagine now' (23.5.1909). The cure appears to have been effective despite much seasickness, for within ten years Vivian was a successful tea and rubber planter in Ceylon.

Both Earland and Thompson seem to have suffered from rather frequent minor health complaints, such as colds and weak chests, to the extent of their work being interrupted. During the First World War Earland had little time for anything except his official duties, which occupied 12 and often 14 hours a day. In 1920 he could report that he had time to 'do a good deal in winter weekends with Allen’ (19.10.1920). 
The fact that he continued at all is a measure of Earland's dedication to his subject. In earlier, and presumably more leisurely, days he observed that 'this microscopic examination is a long business and results often bulk very small compared with the time consumed, especially when the material is poor' (26.8. 1907), but it is unlikely that he ever regretted those hours spent at the microscope. His honesty regarding his own abilities as a young man is seen in response to Thompson's request to describe some new Arctic faunas from the Challenger expedition: 'my experience is not sufficiently extensive to make sure of it being done properly and unless properly done it is better left alone' (17.4.1900). Earland did undertake this task, and many more, with Thompson's encouragement; presumably the study of Foraminifera would have been much the poorer if this fruitful correspondence had never occurred.

\section{ACKNOWLEDGEMENTS}

We are grateful to staff at the Bute Building, St Andrews who first brought the slide collection to our attention and to Professor Pat Wilmer, curator of the Bell-Pettigrew Museum, for permission to examine them. We would also like to thank $\mathrm{Mr}$ Robert Smart and Dr Norman Reid (former and current Keepers of Manuscripts and Muniments, St Andrews University Library) for access to the letters and photographs of the Earland-D'Arcy Thompson collection, reproduced here with their permission. Richard Hodgkinson and John Whittaker very kindly commented on and corrected an early draft of this manuscript. We thank two anonymous referees for their constructive comments.

\section{Manuscript received 29 November 1999 Manuscript accepted 15 March 2001}

\section{REFERENCES}

Earland, A. 1943. Edward Heron-Allen, F.R.S. Journal of the Royal Microscopical Society, 63: 48-50.

Earland, A. \& Cooke, J. H. 1891. Notes on the Recent Foraminifera of Malta. Mediterranean nat., 1: 57-59.

Haynes, J. R. 1981. Foraminifera. Macmillan, London, 433pp.

Hedley, R. H. 1958. Mr Arthur Earland. Nature, 181: 1440-1441.

Heron-Allen, E. \& Earland, A. 1908. On Cycloloculina, a new generic type of Foraminifera. With a preliminary study of the foraminiferous deposits and shore-sands of Selsey Bill. Journal of the Royal Microscopical Society, 1908: 529-543.

Hill, W. 1915. Chalk Boulders from Aberdeen and Fragments of Chalk from the Sea Floor off the Scottish Coast. Proceedings of the Royal Society of Edinburgh, 35: 263-296.

Hodgkinson, R. L. 1989. The Heron-Allen and Earland Type Slide Collection of Foraminifera in the British Museum (Natural History). Journal of Micropalaeontology, 8: 149-156.

Macfayden, W. A. 1959. Arthur Earland. Journal of the Royal Microscopical Society, 7(3-4): 146-150.

Morley-Jones, A. 1958. Arthur Earland (1866-1958). Journal of the Quekett Microscopical Club, ser.4, 5(4): 109-110.

Rice, A. L. 1986. British Oceanographic Vessels 1800-1950. The Ray Society, London, 193pp.

Thompson, D'A. W. 1917. On Growth and Form. Cambridge University Press, London, 793pp.

Thompson, R. D. 1958. D'Arcy Wentworth Thompson: The Scholar Naturalist. Oxford University Press, London, 244pp.

Williamson, W. C. 1858. On the Recent Foraminifera of Great Britain. Royal Society Publications, London, xx, 107pp. 
M. Robinson \& W. E. N. Austin

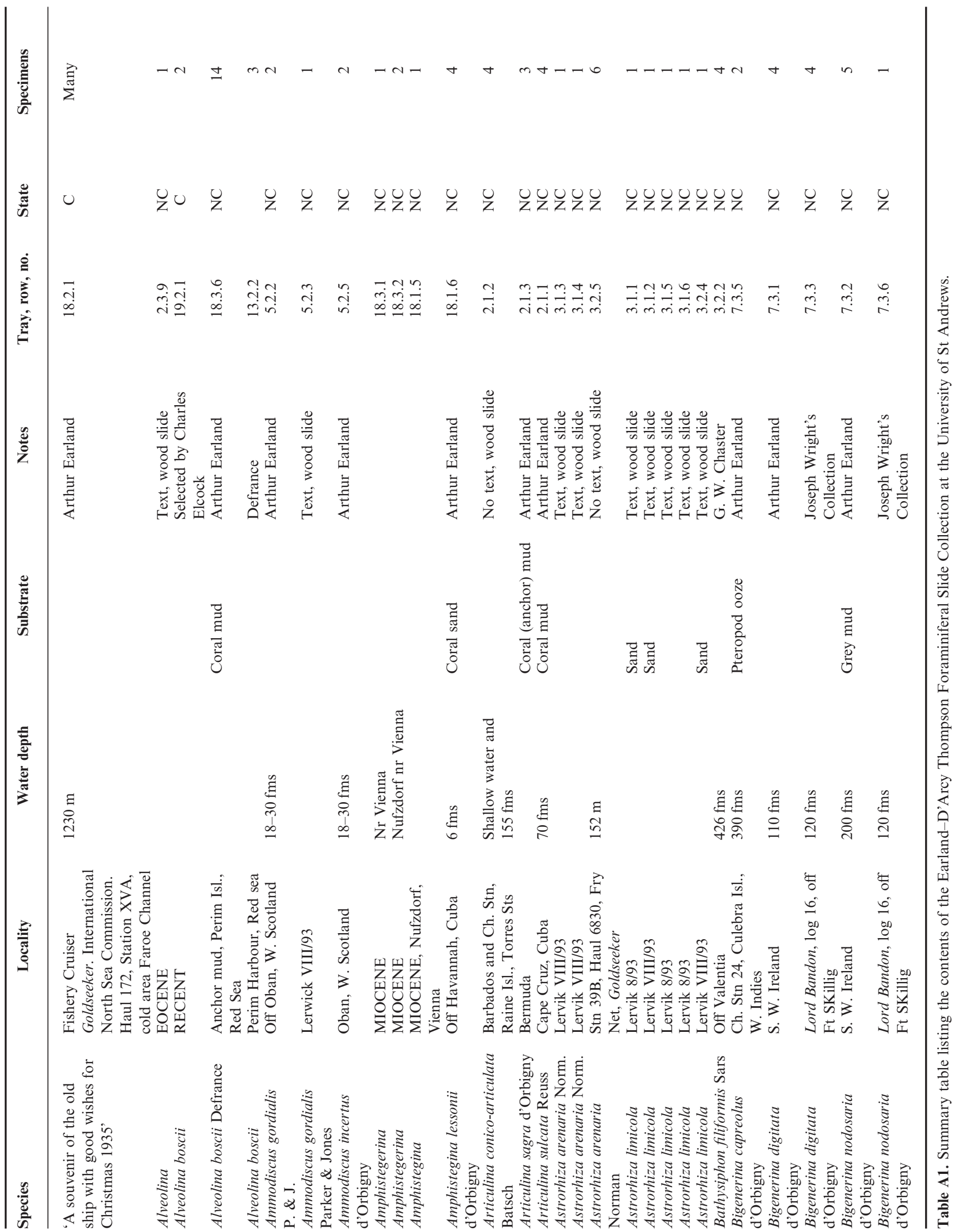




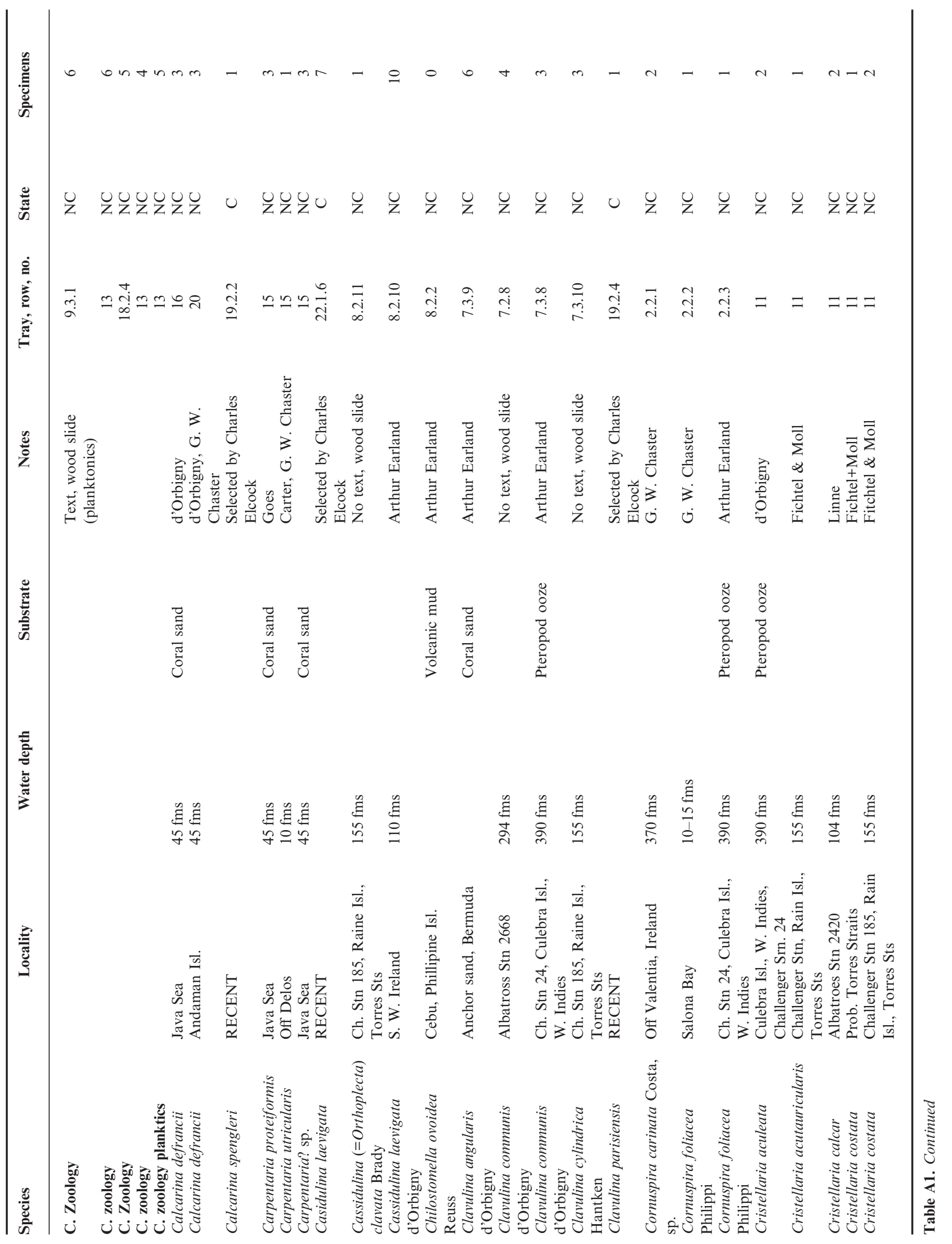




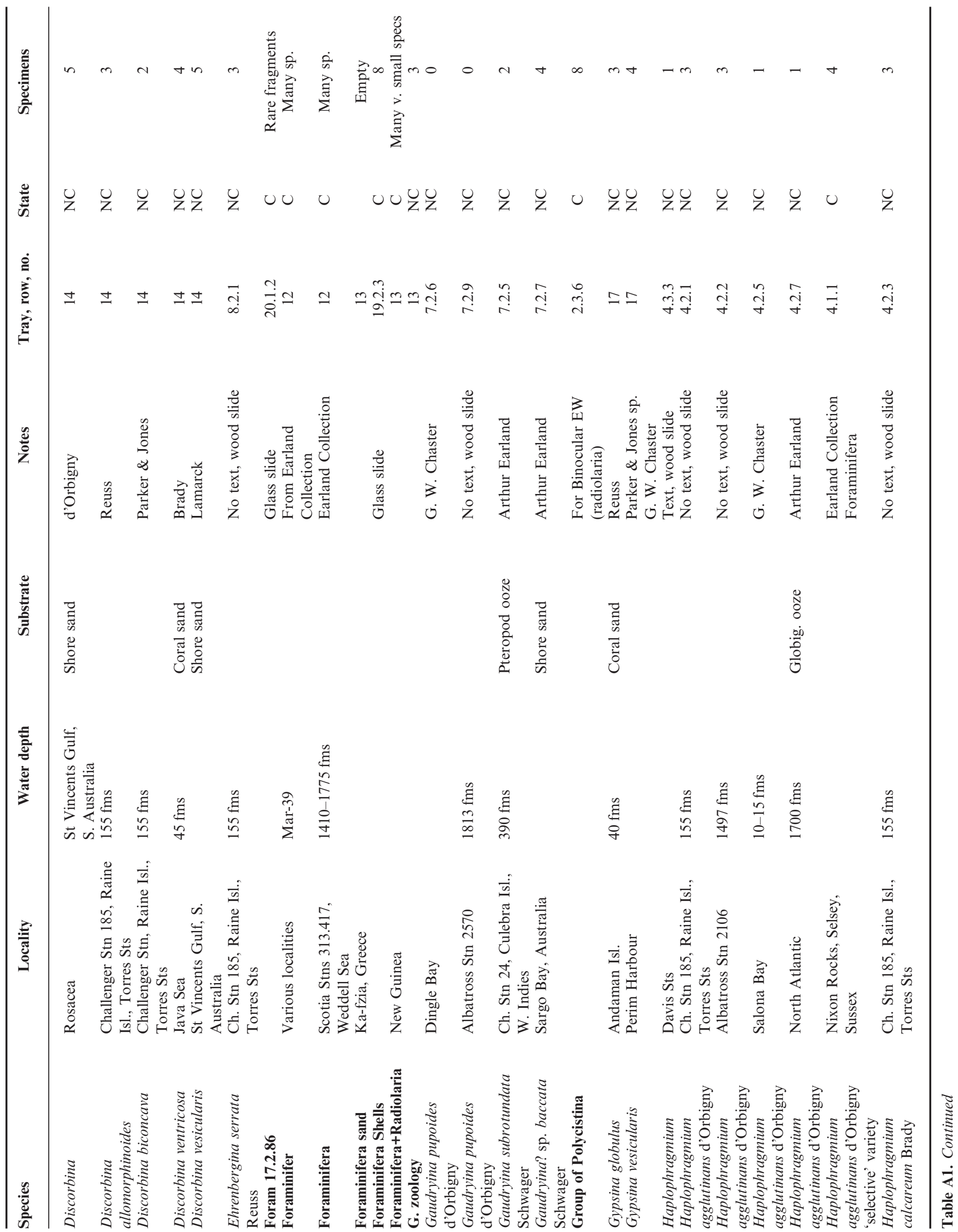


Arthur Earland

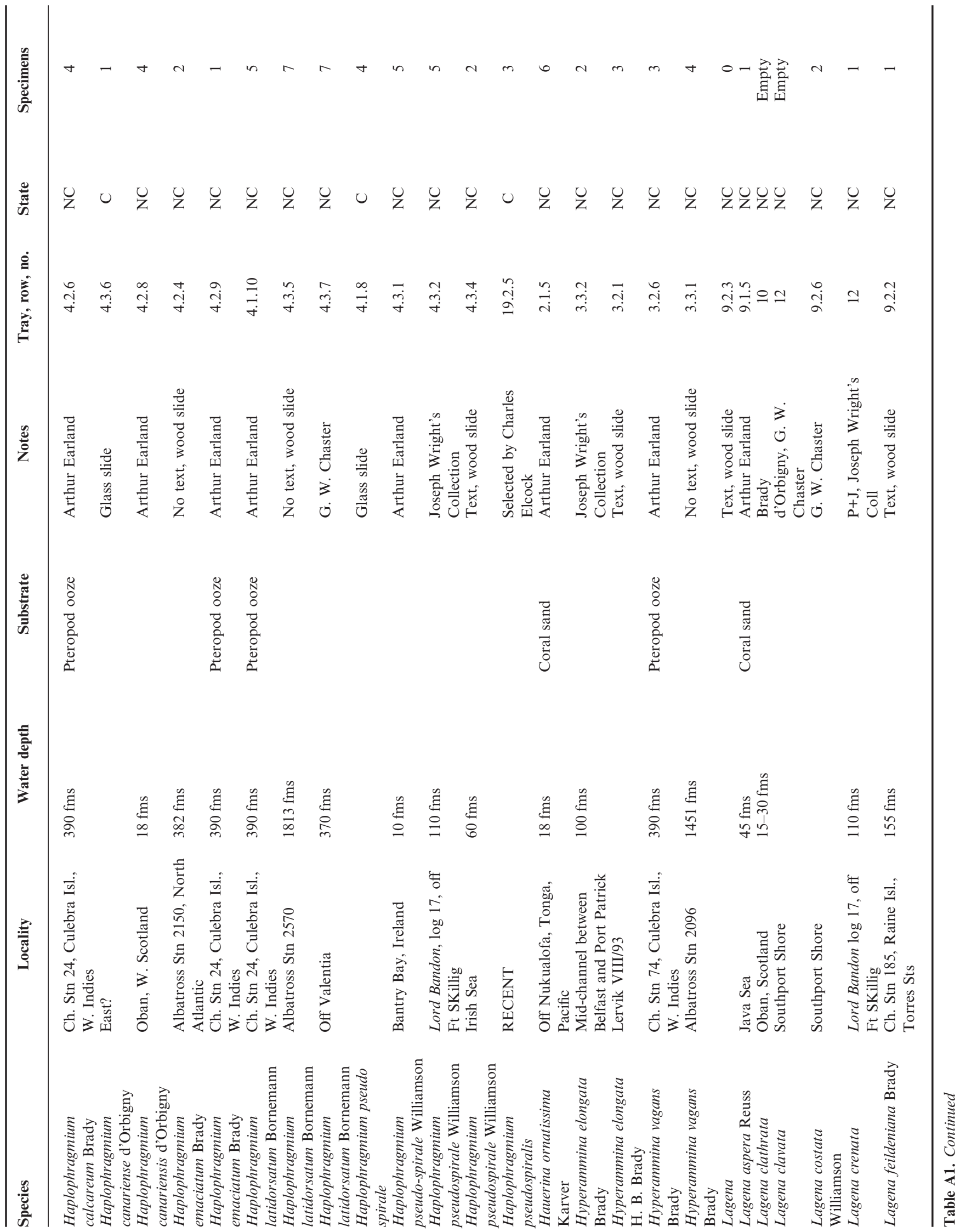




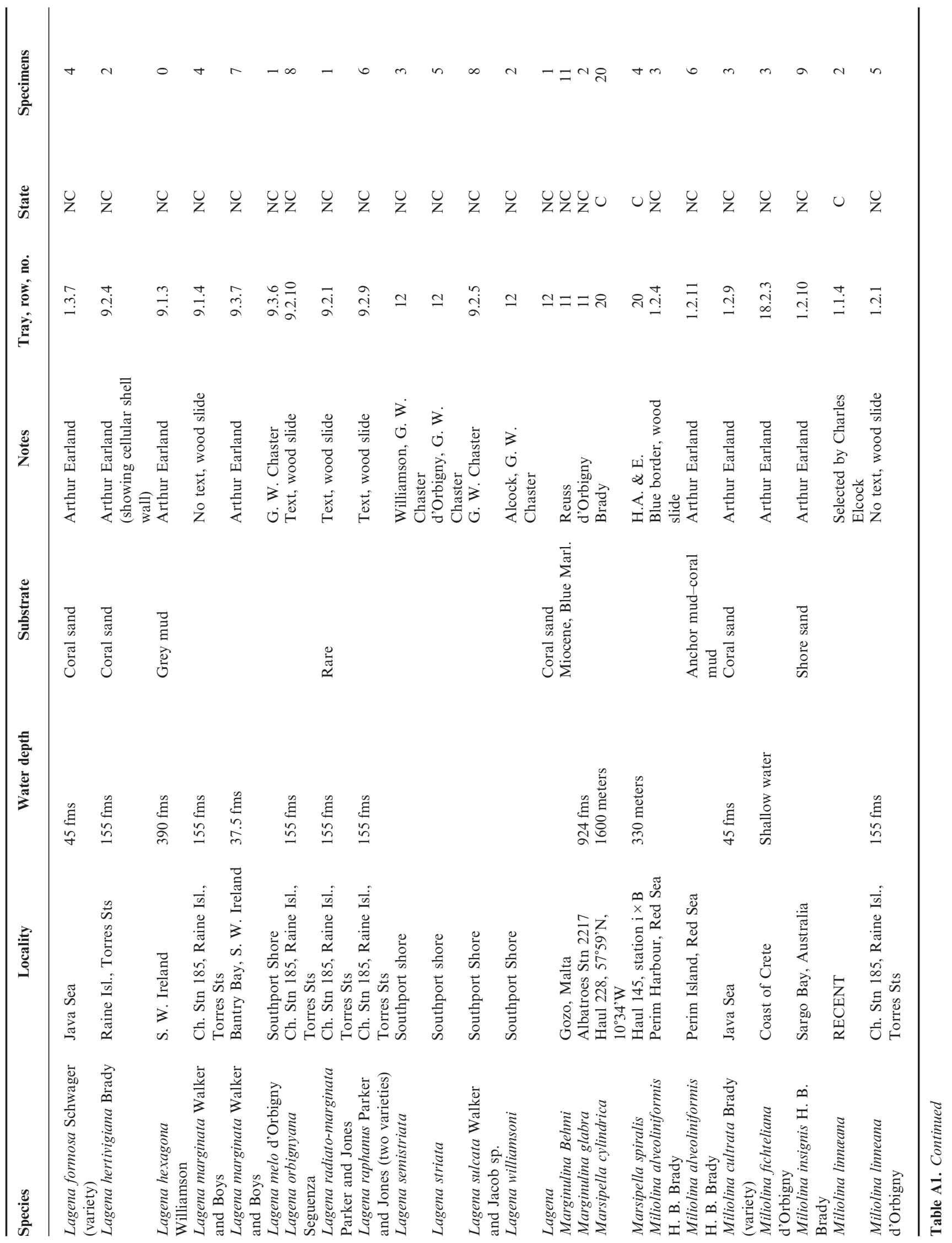


Arthur Earland

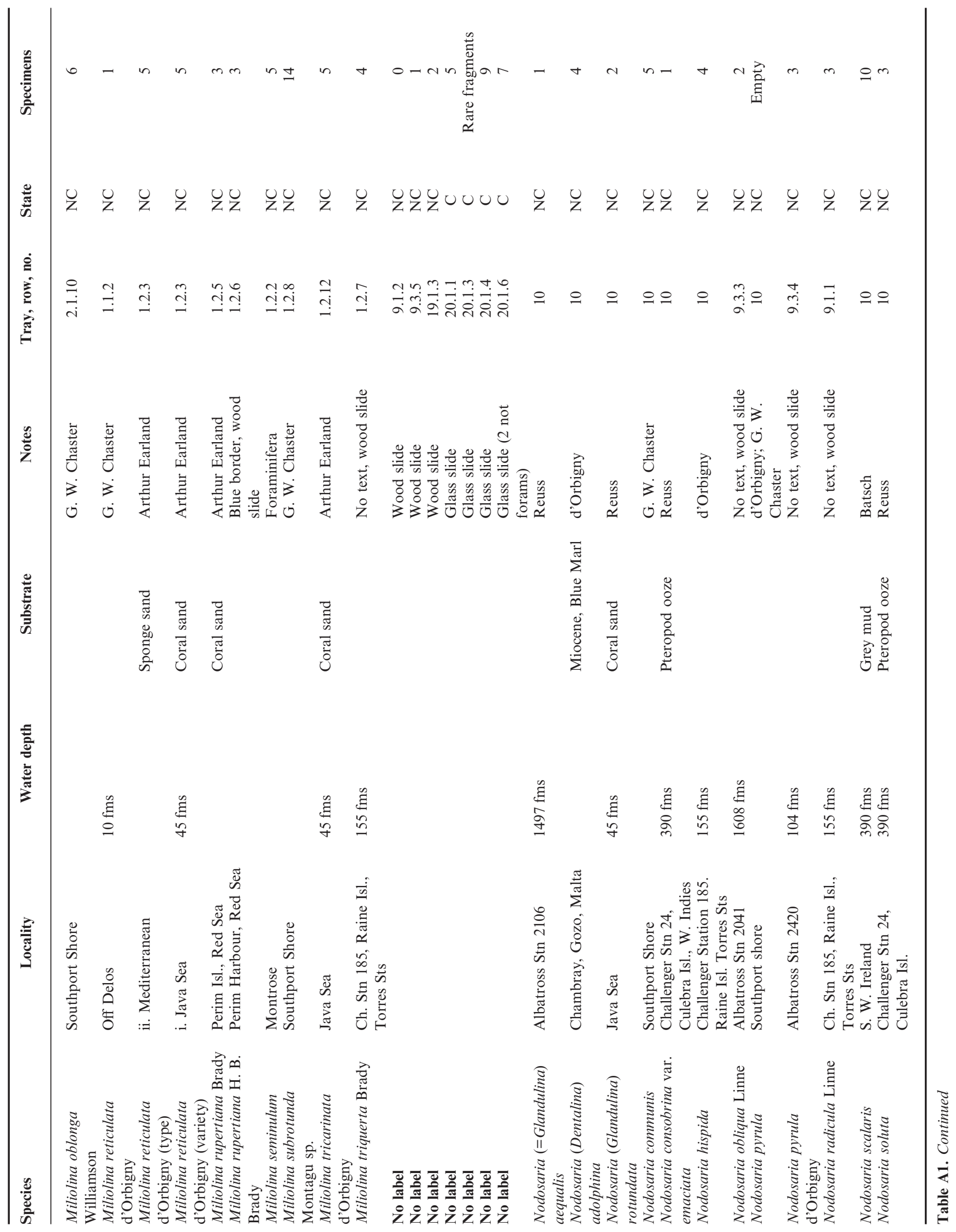




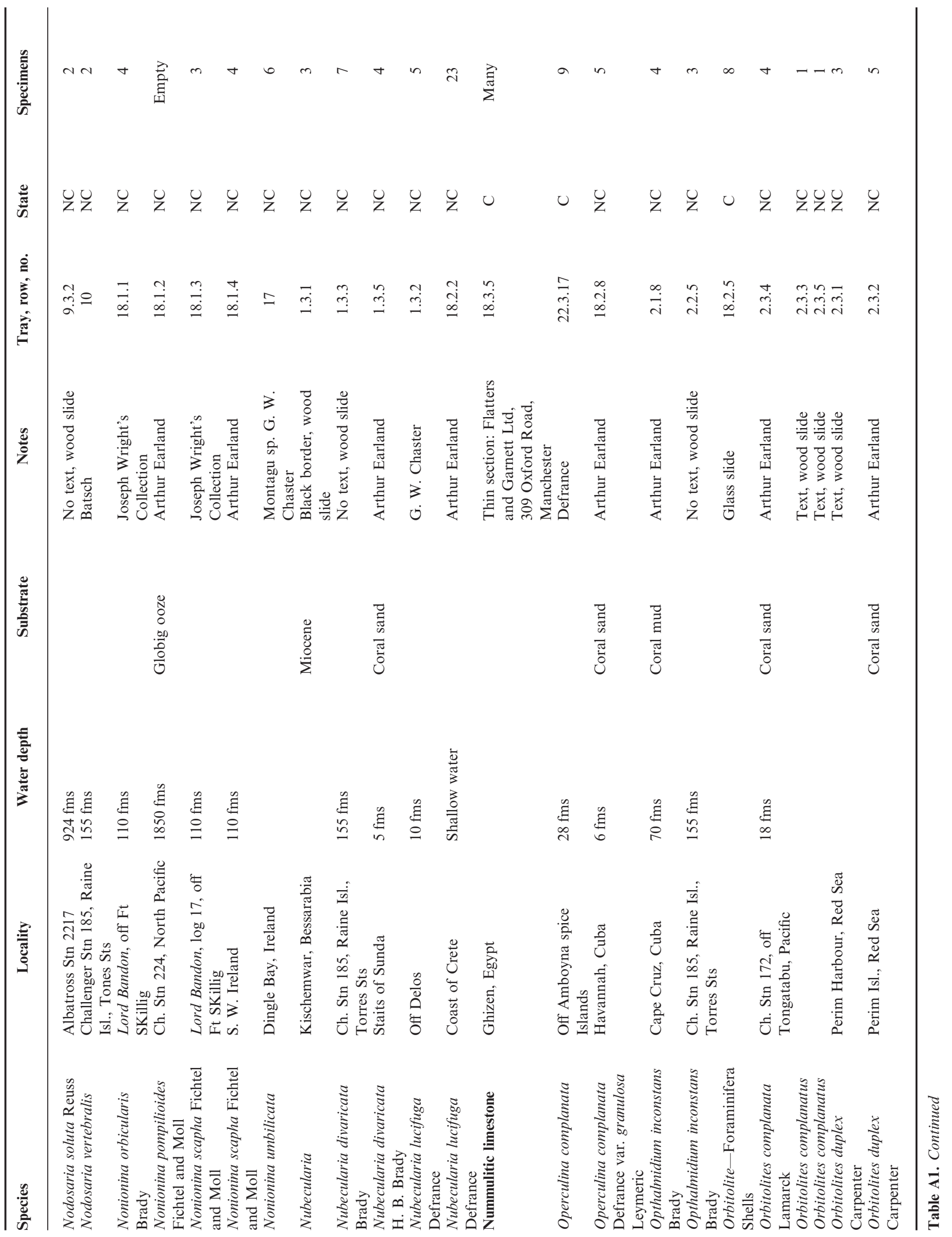


Arthur Earland

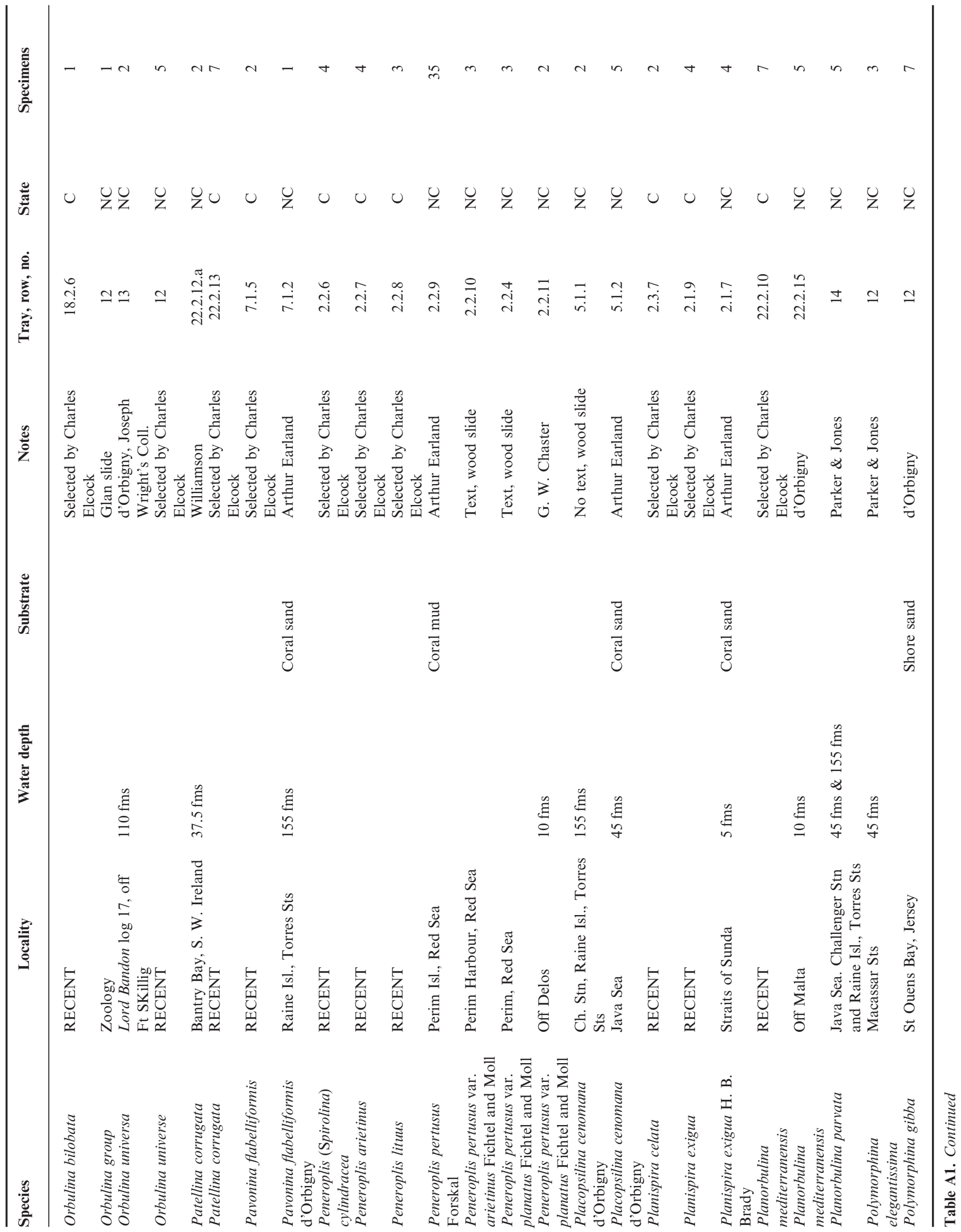




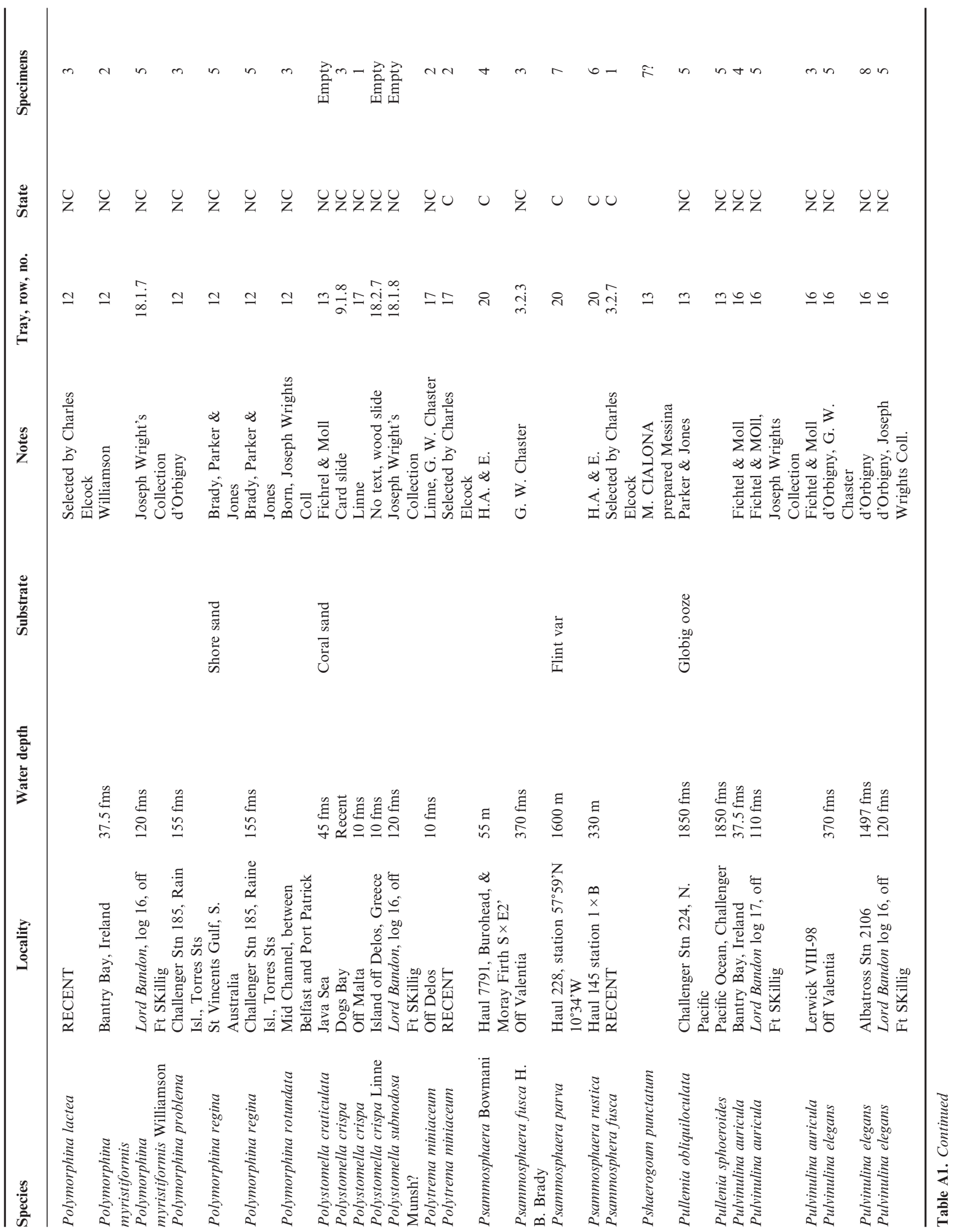


Arthur Earland

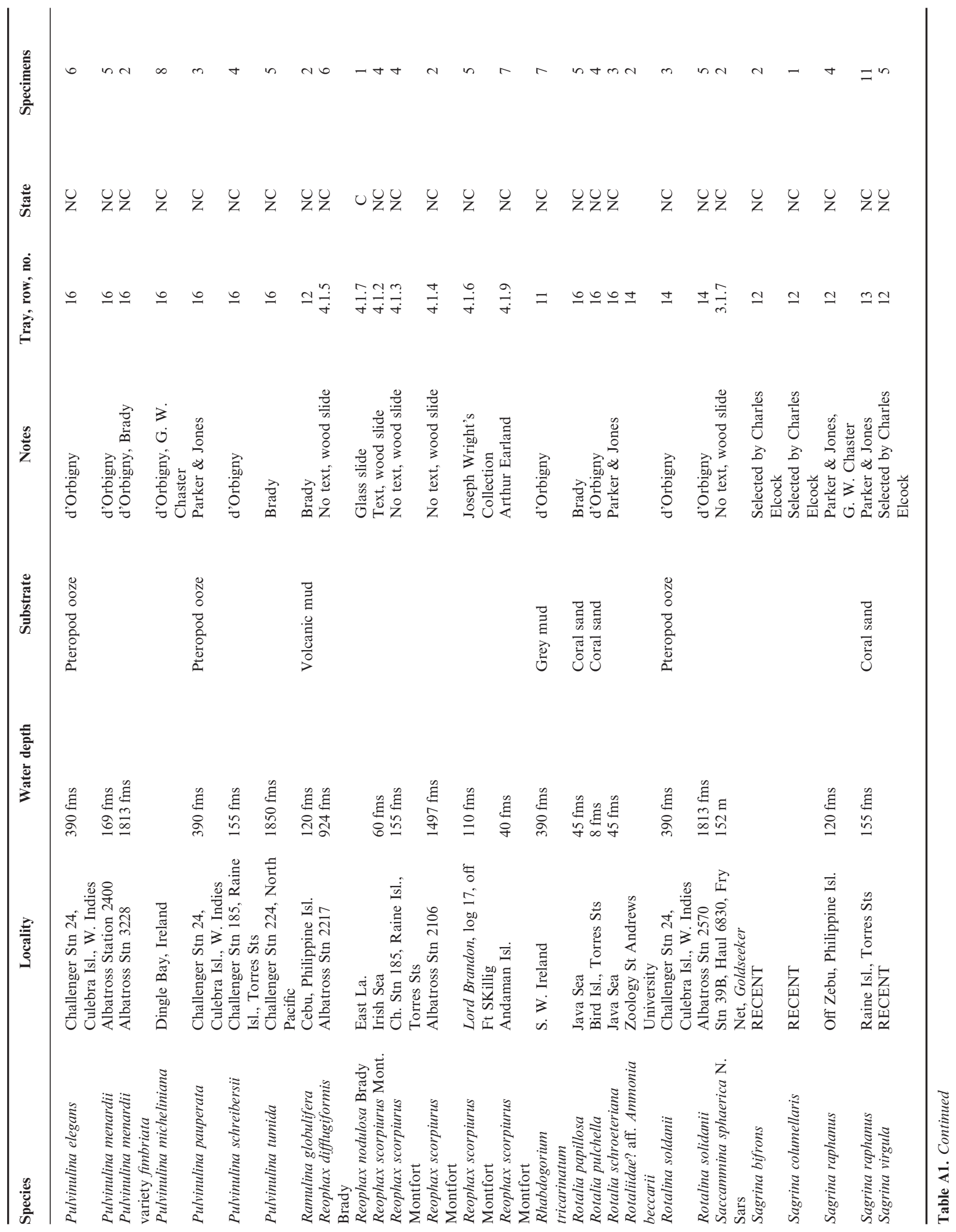


M. Robinson \& W. E. N. Austin

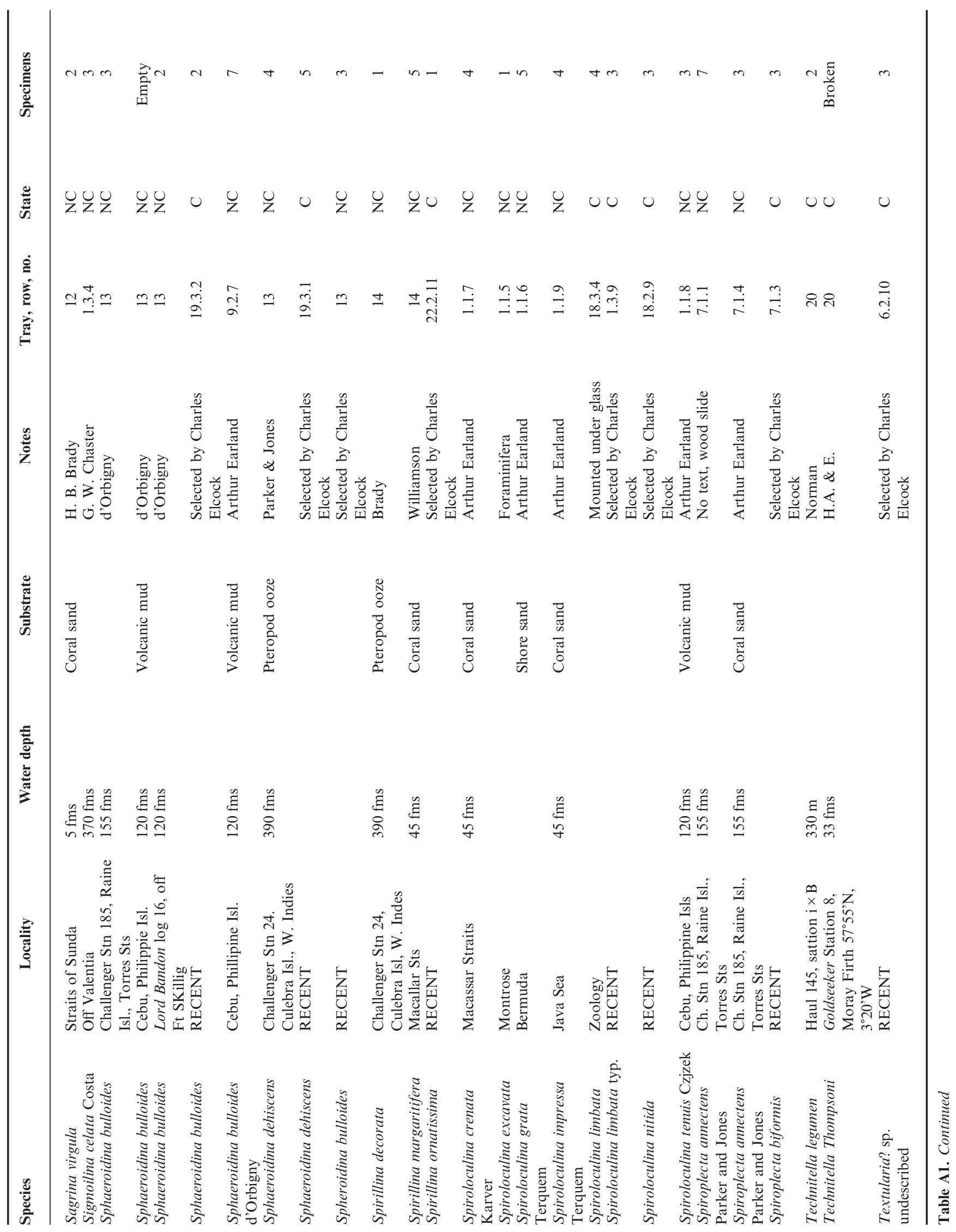




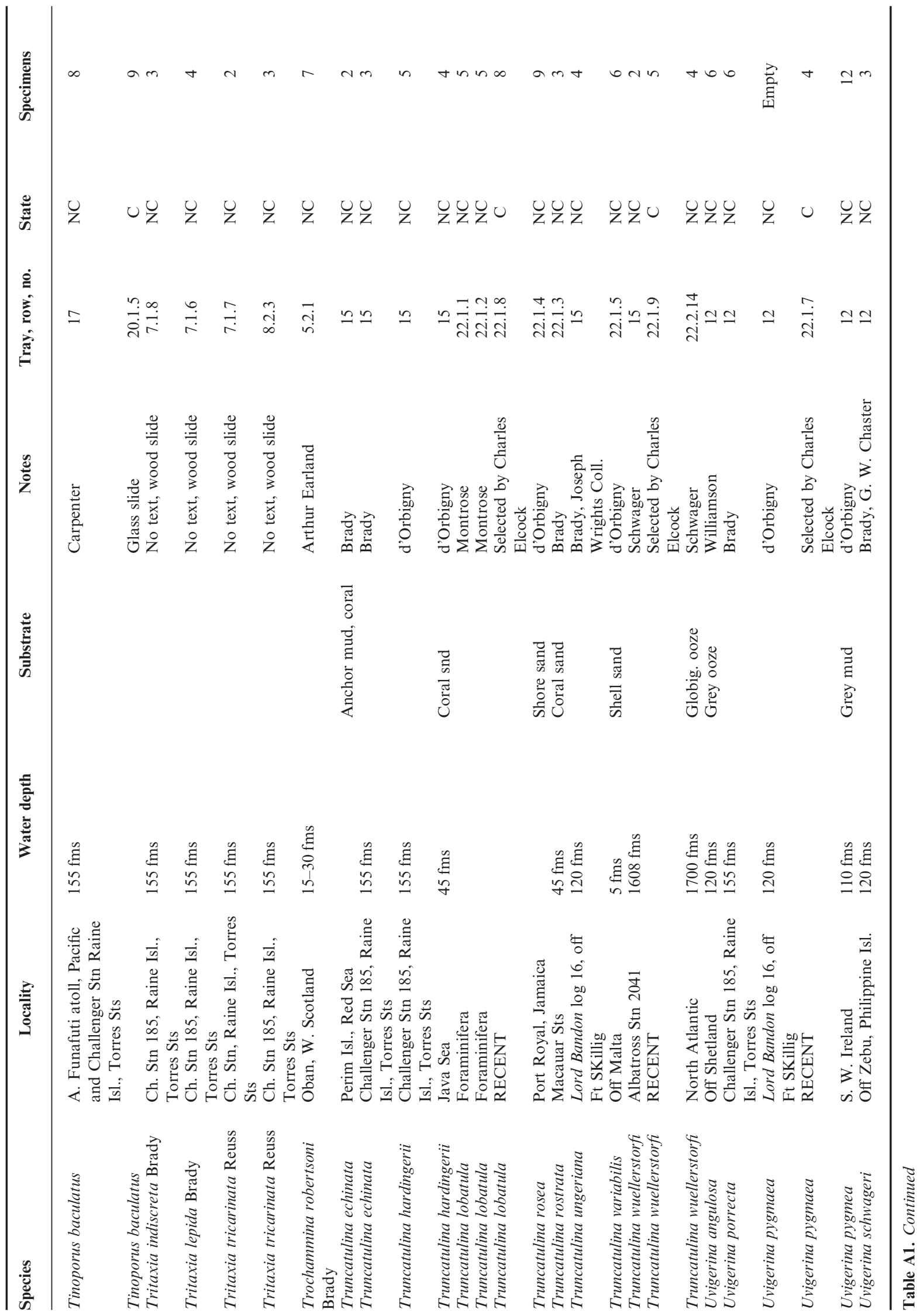


Arthur Earland

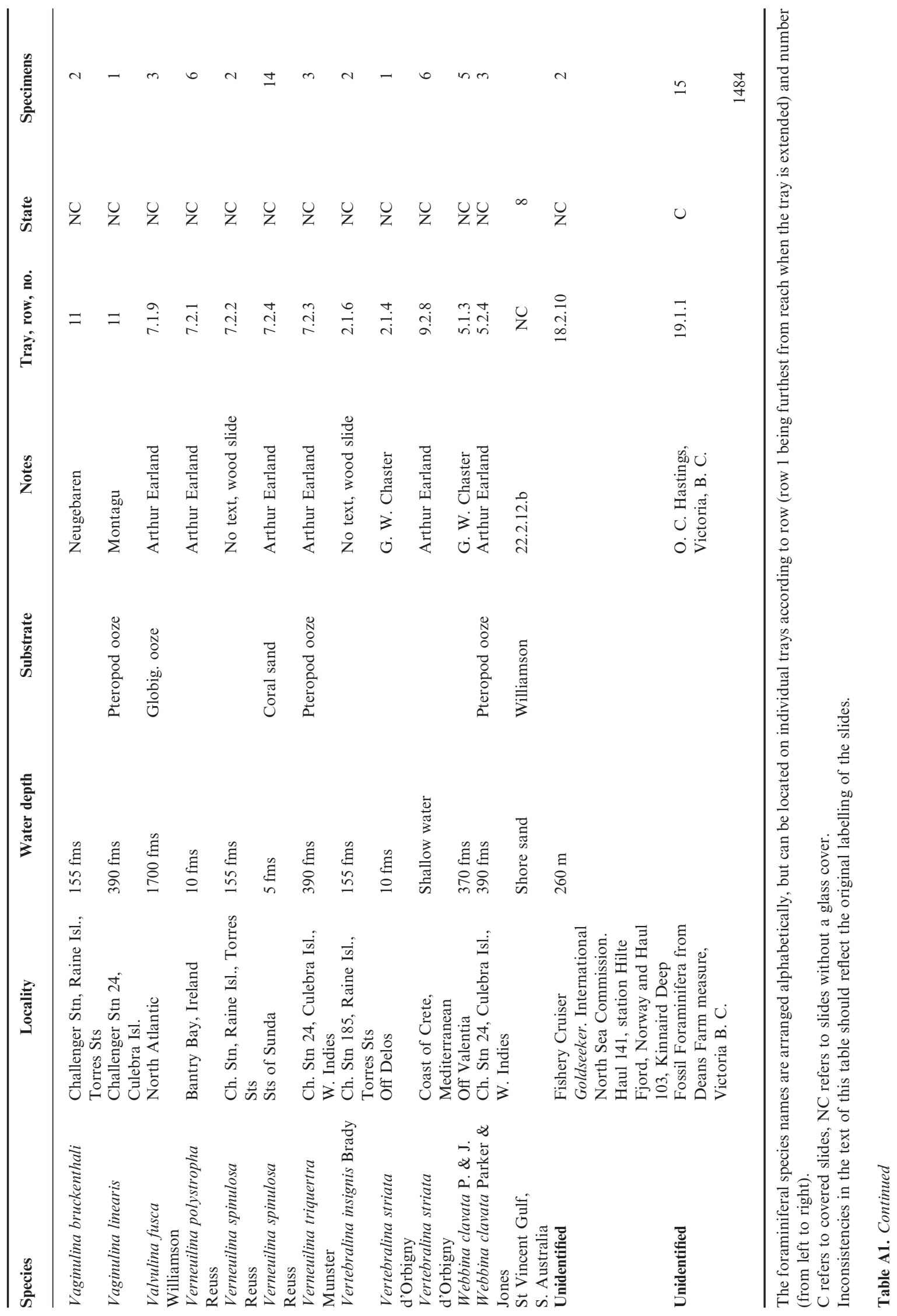




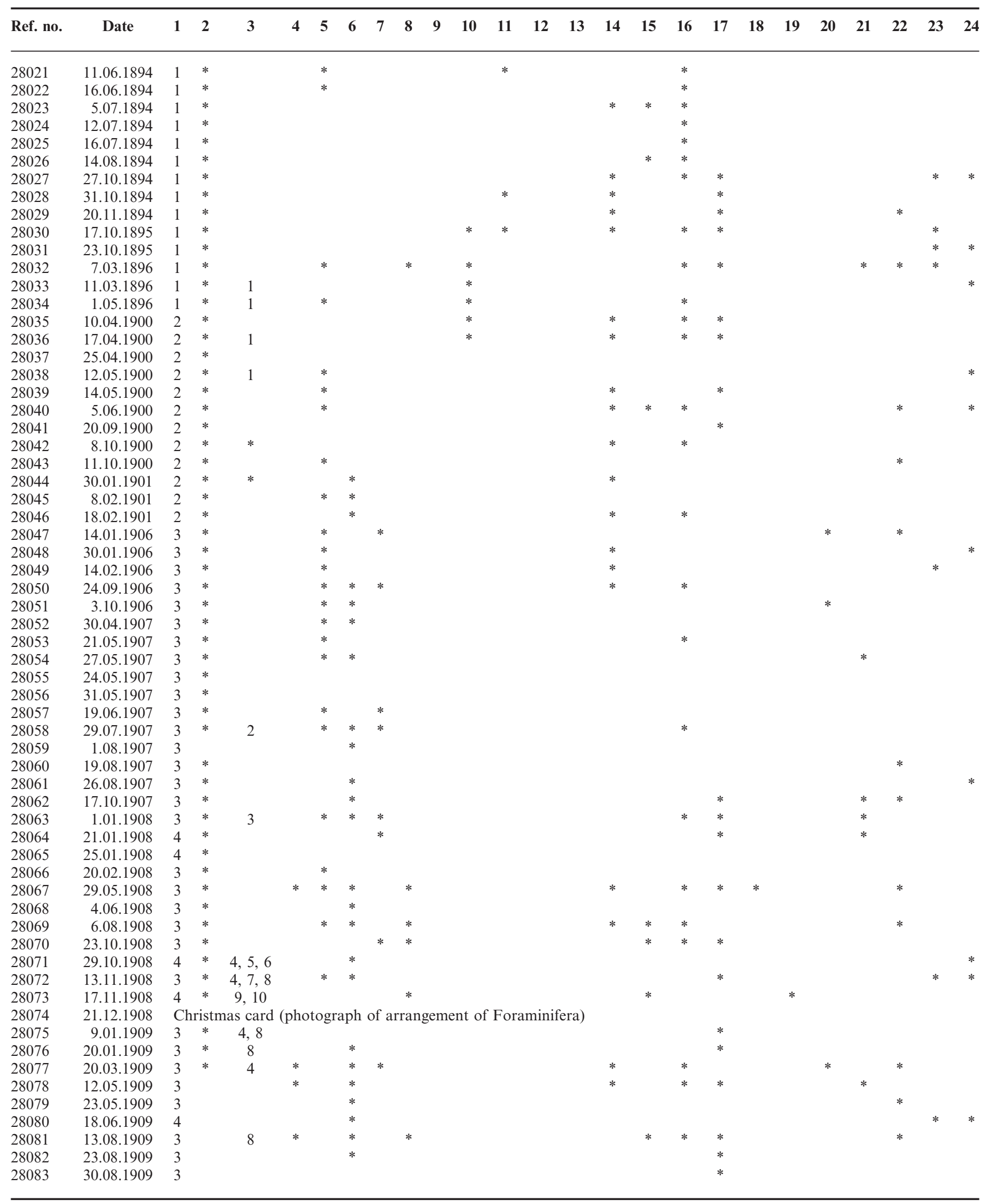

Table A2. Summary table listing the Earland-D'Arcy Thompson correspondence between 11.6.1894 and 6.11.1946. 
Arthur Earland

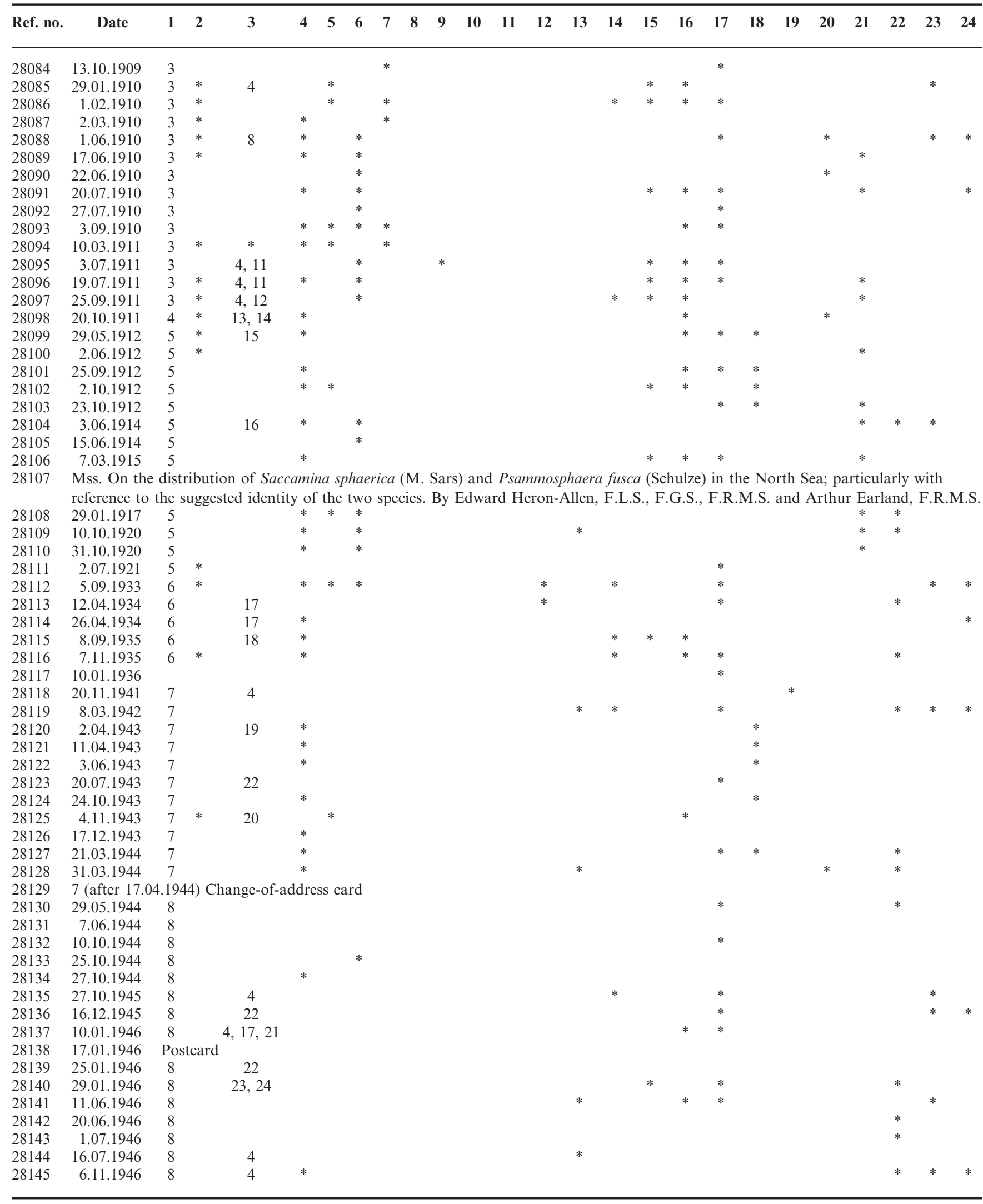

Table A2. Continued 


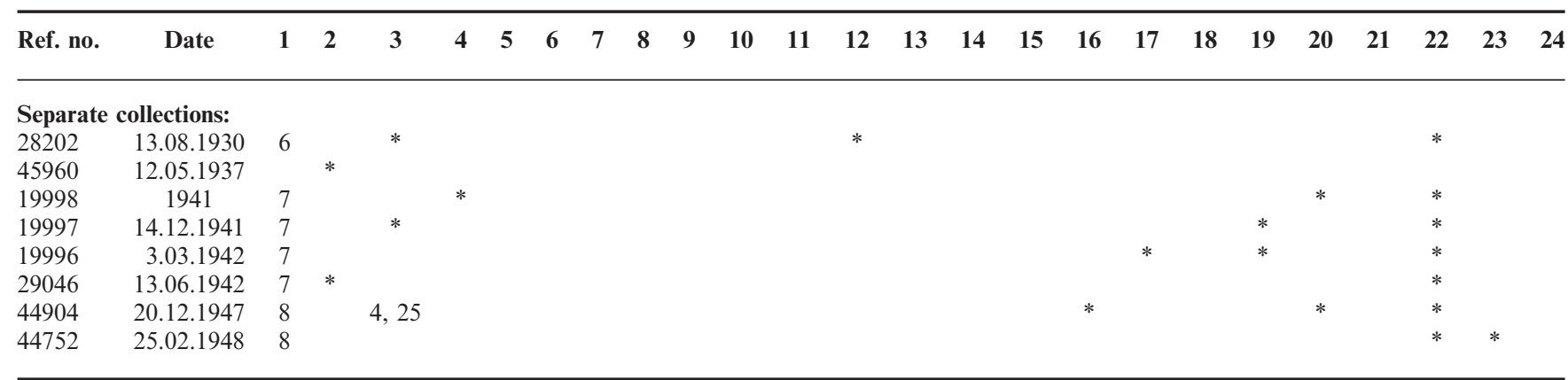

Ref. no., St Andrews University Library catalogue reference number identifying each letter written by Earland to D'Arcy Thompson.

Column 1, address: 1, 10, Glenwood Road, Catford, (London) S.E; 2, 28, Glenwood Road, Catford, S.E; 3, Reading Villa, 31, Denmark Street, Watford; 4, P.O.S.B., West Kensington; 5, 34, Granville Road, Watford; 6, 23, Clive Avenue, Hastings, Sussex; 7, 7, Barony Terrace, Edinburgh 12; 8, 24, Kerrington Crescent, Broughty Ferry.

Column 2, reference to, or to work for, D'Arcy Thompson.

Column 3, reference to, or to work for, other scientists: 1, Dr Chaster; 2, Dr Scott; 3, Mr Joseph Wright; 4, Dr Colman; 5, Mill; 6, Fowler; 7, C. D. Sherborn; 8, W. Hill; 9, Tait; 10, H. S. Martin; 11, Borley; 12, A. Gibb; 13, Kirkpatrick; 14, J. N. Shoebotham; 15, Rhumbler; 16, J. J. Simpson; 17, Dr W. A. Macfadyen; 18, Bruce and Pearcey; 19, Millett; 20, Dr and Mrs Earle H. Myers; 21, M. Davies; 22, A. W. Dennis; 23, Dighton Thomas; 24, Mr E. G. Bailey; 25, Tierney, Peacock, Marie, John.

Column 4, reference to, or to work with, E. Heron-Allen.

Column 5, laboratory preparation and other techniques.

Column 6, Goldseeker and Fisheries Board.

Column 7, North Sea. Column 8, Shetland area. Column 9, St Kilda. Column 10, Greenland. Column 11, Arctic. Column 12, Antarctic. Column 13, St Andrews. Column 14, other places. Column 15, ecology. Column 16, named species. Column 17, general scientific interest. Column 18, Royal Microscopical Society. Column 19, Royal Society of Edinburgh. Column 20, Quekett Club duties. Column 21, GPO work. Column 22, home and family. Column 23, health: A. Earland. Column 24, health: D’Arcy Thompson.

Table A2. Continued 